\title{
FOTO (E) GRAFIAS NA FORMAÇÃO DE PROFESSORES/AS DE EDUCAÇÃO FÍSICA
}

\section{ADMIR SOARES DE ALMEIDA JUNIOR}

Universidade Federal de Minas Gerais

RESUMO

Nesse texto, apresento uma reflexão sobre o lugar ocupado pelas narrativas (visuais, orais e escritas) no processo de formação (inicial e continuada) de professores/as de educação física. Para tanto, narro, inicialmente, como seu deu minha aproximação com o campo da Pesquisa Narrativa e (Auto)biográfica, bem como a um conjunto de estudos relacionados à utilização de imagens (fotográficas), nas pesquisas em ciências sociais. Em seguida, tendo como referência alguns desafios colocados ao processo de formação de professores/ as de educação física, destaco algumas experiências desenvolvidas no âmbito da formação de docentes desse componente curricular, que tomam as imagens fotográficas e as narrativas como elementos estruturantes. Dessa forma, parece-me correto afirmar que a produção de diferentes tipos de narrativas tem se configurado em uma relevante estratégia de formação e desenvolvimento profissional dos sujeitos envolvidos.

Palavras-chave: Narrativas. Fotografia. Professores/as de Educação Física. Formação.

\section{ABSTRACT PHOTO (AND) GRAPHS IN PHYSICAL EDUCATION TEACHERS' EDUCATION}

In this text, I present a reflection on the space (visual, oral and written) narratives occupy in the physical education teacher's education process (including continuing education). To do so, I initially describe how I first came to know about the Auto/Biographical Narrative Research field, as well as to a collection of studies related to the use of (photographic) images in social science researches. Next, having some challenges posed to the physical education teacher's education process as reference, I highlight a few experiences - based on the scope of licensure of this curricular component - that have photographic images and narratives as structural elements. Therefore, it seems proper to state that the production of different types of nar- 
ratives has become a relevant strategy for training and professional development of the individuals/subjects involved.

Keywords: Narratives. Photography. Physical Education Teachers. Teacher's Education.

\section{RESUMEN FOTO (E) GRAFIAS EN LA FORMACIÓN DE PROFESORES/AS DE EDUCACIÓN FÍSICA}

Nesse texto presento una reflexión sobre el lugar ocupado por las narrativas (visuais, orais y escritas) no proceso de formación (inicial y continuada) de profesores/as de educación física. Para tanto, inicialmente narro como su dio mi acercamiento con el campo de la Investigación Narrativa y (Auto) biográfica, como un conjunto de estudios relacionados con las imágenes (fotográficas). Em seguida, tendiendo como referencia algunos desafios colocados en el proceso de formación de profesores/as de educación física, destaco algunas experiencias desarrolladas en el ámbito de la formación de docentes de los componentes curriculares que toman las imágenes fotográficas y narrativas como elementos estructurantes. Dessa forma, parece que se ha elaborado una producción de diferentes tipos de narrativas y se ha configurado en una estrategia de formación y desarrollo profesional de los sujetos involucrados.

Palabras clave: Narrativas. Fotografia. Profesores/as de Educación Física. Formación.

\section{Algumas Palavras Iniciais}

Sou professor de educação física. Concluí minha licenciatura no ano de 1992. Ao longo de minha prática profissional, atuei por 22 anos como docente dessa disciplina em escolas na Rede Municipal de Educação de Belo Horizonte e, nos últimos 10 anos, venho atuando também no ensino superior, com a formação de docentes desse componente curricular.

Desde o ano de 2008, em função de minha inserção no Grupo de Estudos e Pesquisas em Educação Continuada (GEPEC) da Faculdade de Educação da Universidade Estadual de Campinas (FE/UNICAMP), tenho buscado incorporar a minha prática docente a produção de textos (auto)biográficos que, de algum modo, permi- tam uma reflexão individual e coletiva sobre os diferentes contextos de formação docente.

Meu convívio no GEPEC possibilitou entender que a narrativa é uma dimensão fundamental da comunicação humana e de atribuição de significado ao mundo. Para Larossa Bondía (2004):

El ser humano es um ser que se interpreta y, para esa autointerpretación, utiliza fundamentalmente formas narrativas. [...] y ese particular y casi omnipresente género discursivo que es la narrativa. De hecho, el sentido de lo que somos o, mejor aún, el sentido de quién somos, tanto para nosotros mismos como para los otros, depende de las historias que contamos y que nos contamos y, em particular, de aquellas construcciones 
narrativas em lãs que cada uno de nosotros es, a la vez, el autor, el narrador y el carácter principal, es decir, de las autobiografias, autonarraciones o historias personales.' (2004, p. 12-13)

O autor faz um convite para considerarmos a narrativa como uma ação humana espontânea. Para construir sentido e significado para nossa presença no mundo, estamos constantemente a nos autobiografar. Segundo Passeggi (2010), estamos frequentemente elaborando autobiografias involuntárias, que vão construindo rascunhos de nossas identidades. Dessa forma, a narrativa permite a (re)construção de nossas imagens e (auto)imagens, no monólogo interior e no diálogo com o outro.

Para Benjamin (1994), a narrativa encontrase intimamente relacionada ao ato de rememorar e à possibilidade de ressignificar a própria experiência através de memórias repletas de significados, sentimentos e sonhos. $O$ ato de rememorar possibilita que dimensões pessoais - fundamentalmente a experiência - que vêm sendo perdidas no contexto da sociedade moderna, possam ser recuperadas numa trama temporal que articula passado, presente e futuro. 0 narrador, para Benjamim, possui a característica de saber aconselhar, o que torna a vida a matéria prima da experiência - nossa e dos outros - potencializando assim a transformação da mesma. Para o autor, o ato de rememorar e narrar se faz a partir do presente, é o presente que possibilita nosso deslocamento em direção ao passado e ao futuro, em viagens que nos permitem (re)construir nexos da nossa história e de nossa vida.

1 O ser humano é um ser que se interpreta e, para essa autointerpretação, utiliza formas narrativas fundamentalmente. [...] e esse gênero discursivo particular e quase omnipresente que é a narrativa. De fato, o senso de quem somos ou, melhor ainda, o senso de quem somos, tanto para nós mesmos quanto para os outros, depende das histórias que contamos e que nos contamos e, em particular, sobre essas construções narrativas em que cada um de nós é, ao mesmo tempo, o autor, o narrador e o personagem principal, isto é, autobiografias, autorrelatos ou histórias pessoais.
Pesquisa Narrativa e (auto) biográfica na formação de professores/as (de educação física)

Os conceitos de narrativa, história de vida e (auto)biografia, são cada vez mais utilizados por pesquisadores nas ciências sociais e na educação. 0 campo da investigação narrativa abarca uma gama diferenciada de manifestações e pressupostos teóricos e metodológicos, entretanto a constituição do mesmo pode ser relacionada a um contexto de "insatisfação das ciências sociais em relação ao tipo de saber produzido e da necessidade de uma renovação dos modos de conhecimento científico" (NÓVOA, 2000, p. 18).

Alguns autores, dentre os quais destaco Botía (2002), consideram que a perspectiva de investigação biográfica e narrativa se constituiu como campo de estudos no contexto do "giro hermenêutico", produzido nos anos de 1970 pelas ciências sociais. Nesse sentido, a partir de um movimento de oposição a um modo de cientificidade hegemônico na modernidade passa-se a uma perspectiva interpretativa, na qual os sentidos e significados produzidos pelos sujeitos se convertem no foco central dos estudos e pesquisas.

No âmbito dos estudos sobre formação e desenvolvimento profissional de professores/ as, Goodson (2008) destaca que é encorajador perceber que a ênfase dada às histórias e narrativas dos/das professores/as significa uma mudança na forma de apresentar e representar os docentes. Ainda segundo o autor, a investigação narrativa permite aprofundar nossos entendimentos sobre a vida e o trabalho dos/das professores/as.

Conhecer, discutir e refletir sobre e com as histórias de vida, as memórias, as narrativas dos/das professores/as como produção de conhecimento não é algo novo no campo da 
educação. Entretanto, a pesquisa produzida no campo da formação docente em educação física, até o momento, pouco tem se aproximado dessa perspectiva.

No tocante à formação inicial de professores/as de educação física, Terra (2010) utilizase de uma dimensão denominada pela autora de Biográfica-Narrativa, como uma estratégia no processo de formação de professores de educação física. No contexto de um curso de licenciatura, os acadêmicos produzem textos autobiográficos - no formato de memoriais - que posteriormente são retomados e analisados e, eventualmente, reescritos em alguns momentos de sua trajetória de formação inicial.

No que diz respeito ao processo de desenvolvimento profissional de professores/as de educação física, os estudos e pesquisas que se utilizam de narrativas, com o intuito de compreender os saberes produzidos pelos docentes no cotidiano das escolas, são ainda mais incipientes. Nesse sentido, concordo com Prado e Damasceno (2007):

[...] a narrativa é um modo de organização legítimo para que os professores e professoras exponham seus saberes e experiências e construam instâncias de trocas a partir destas, e nestas, maneiras de dizer. Os saberes docentes se constroem pelo significado que cada professor/professora, enquanto autor/autora confere à atividade docente no seu cotidiano a partir de seus valores, de seu modo de situar-se no mundo, de sua história de vida, de suas representações, de seus saberes, de suas angústias e anseios, do sentido que tem em sua vida o ser professor e professora. (PRADO; DAMASCENO, 2007, p. 25)

Nesse ponto, parece-me pertinente apresentar algumas reflexões sobre os "novos" desafios apontados à formação de professores/ as de educação física no Brasil, baseando-me nas contribuições de Figueiredo (2010) e buscando articulá-las ao campo das pesquisas narrativa e (auto)biográfica. Nos últimos vinte anos, vários estudiosos do campo da educação física têm se debruçado sobre a temática da formação de professores/as desse componente curricular. Figueiredo (2010) destaca que, de um modo geral, ainda permanecem um conjunto de desafios mais gerais, tais como: a falta de articulação entre teoria e prática e a dicotomia entre formação específica e formação pedagógica, discutidos pelos estudiosos da educação. A esses desafios somam-se outros, mais específicos à formação de professores/ as de educação física: a necessidade de construção de uma sólida formação; a ausência de uma conexão entre as disciplinas da formação específica e as disciplinas básicas; a ausência de uma identidade profissional e a falta de clareza acerca do seu objeto de estudo.

Nesse momento, dada a especificidade desse texto, não pretendo discutir todas as dimensões dos desafios elencados por Figueiredo (2010). Considero todas importantes, entretanto, buscarei enfatizar duas dimensões: uma vinculada à formação inicial e outra relacionada à formação continuada.

Em relação à formação inicial, o diálogo com Figueiredo (2010) possibilitou a elaboração dos seguintes questionamentos: que estratégias podem ser elaboradas para fazer com que os alunos de educação física valorizem o processo de sua formação como futuros docentes? Como produzir vivências significativas ao longo do processo de formação inicial que possibilitem aos alunos se relacionarem com os saberes da docência de forma mais "epistêmica" e menos "utilitária"? Como materializar currículos de formação menos utilitários, normativos e funcionalistas? Isto é, currículos que favoreçam ao futuro professor o lugar de formar-se e não o lugar de ser formado.

No que concerne à formação continuada, as seguintes questões têm mobilizado minhas reflexões: como as mudanças educativas demandadas pelo processo de universalização do 
direito à educação e também pelos educandos - considerados como o principal polo de interrogação da docência - têm impactado os modos dos professores de educação física subjetivarem a sua profissão, de se relacionarem e de viverem a sua condição profissional? Como construir contextos colaborativos de pesquisa, com professores de educação física na educação básica, que favoreçam a explicitação e a circulação dos saberes docentes cotidianos?

As duas experiências apresentadas mais à frente nesse texto - uma no âmbito da formação inicial e outra na formação continuada de professores de educação física - não buscam responder a todas as questões elencadas. Entretanto, considero que as experiências apresentam indícios da pontencialidade da utilização de narrativas visuais, orais e escritas, no processo de formação e desenvolvimento profissional de docentes vinculados a esse componente curricular.

Neste trabalho, baseando-me em Botía (2002), compreendo a narrativa como a qualidade estruturada da experiência entendida e vista como um relato que se constitui em formas de produzir sentido, a partir de ações pessoais, em determinado contexto de tempo e espaço, por meio da descrição e da análise de dados biográficos. A narrativa constitui-se, então, em uma forma particular de reconstrução da experiência, através da qual, mediante um processo de reflexão, dá-se significado ao acontecido ou vivido.

\section{Limiares da Imagem}

Do rigor da ciência

[...] Naquele Império, a Arte da Cartografia alcançou tal Perfeição que o mapa de uma única Província ocupava toda uma Cidade, e o mapa do Império, toda uma Província. Com o tempo, esses Mapas Desmesurados não foram satisfatórios e os Colégios de Cartógrafos levantaram um Mapa do Império, que tinha o tamanho do Império e coincidia pontualmente com ele. Me- nos Afeitas ao Estudo da Cartografia, as Gerações Seguintes entenderam que esse dilatado Mapa era Inútil e não sem Impiedade os entregaram às Inclemências do Sol e dos Invernos. Nos desertos do Oeste perduram despedaçadas Ruínas do Mapa, habitadas por Animais e por Mendigos; em todo País não há outra relíquia das Disciplinas Geográficas. (Suárez Miranda: Viaje de Varones Prudentes, livro quarto, cap. XLV, Lérida, 1658). (BORGES, 1999, p. 27)

Neste tópico apresento meu percurso de aproximação ao campo da visualidade humana. ${ }^{2}$ Além disso, busco compreender também os lugares ocupados pela imagem na sociedade atual, para em seguida mergulhar na singularidade e nas potencialidades heurísticas das imagens fotográficas. Vale destacar que as discussões e reflexões sobre a presença das imagens na sociedade contemporânea são numerosas e abarcam diferentes campos de conhecimento. Para tanto, busco construir um diálogo com e entre autores oriundos de campos de conhecimento diversos, com os quais venho procurando, nos últimos anos, instaurar uma relação de aprendizagem.

De um modo geral, parece-me correto considerar que vivemos em um contexto social onde as imagens se fazem presentes em cada um e em todos os meios da comunicação humana. Como afirma Samain (2006), as imagens povoam o universo da comunicação humana desde a fala até a informática. Desde as famosas pinturas rupestres de mãos negativas das grutas de Pech Merle, que datam do período neolítico, às imagens infográficas produzidas pelos mais potentes processadores dos computadores domésticos, as imagens ocupam um lugar estratégico na constituição e conformação dos mecanismos cognitivos do pensamento e da comunicação humana (SAMAIN, 2006).

Nesse sentido, retomo o estrato do conto

2 Refiro-me a um conjunto de estudos relacionados aos campos da Antropologia e da Sociologia da Imagem, bem como de pesquisas que tomam como foco de análise e reflexão as imagens fotográficas. 
Borges (1999), apresentado na epígrafe desse tópico, por considerar que as imagens devem ser tomadas como uma produção humana, na tentativa de interpretar, representar e conhecer o mundo. As imagens podem e devem ser consideradas como superficies que buscam tanto apresentar como representar algo. As imagens são mediações entre os sujeitos e o mundo. As imagens são mapas. Mapas construídos com o objetivo de apresentar e traçar alguns caminhos possiveis de serem percorridos, ao longo da existência humana. As imagens (os mapas) têm o propósito de representar o mundo.

Para Flusser (2002), o homem está e "existe" no mundo, entretanto, esse mesmo mundo não lhe é acessivel de imediato. As imagens pretendem representar algo que está "lá fora no espaço e no tempo". Para o autor, as imagens são o resultado de um esforço de se abstrair duas das quatro dimensões de espaçotempo, para que se conservem apenas as dimensões do plano. As imagens têm sua origem na imaginação - "A imaginação é a capacidade de fazer e decifrar imagens" (2002, p. 7).

Entretanto, Flusser (2002) chama a atenção para o tipo de relação que o homem vem construindo com as imagens. Ele ressalta que, assim como os cartógrafos do pequeno conto apresentado por Borges, o ser humano utilizase da imaginação para, em vez de se servir das imagens em função do mundo, passar a viver em função de imagens. Ainda segundo Flusser (2002):

[...] Tal inversão da função das imagens é idolatria. Para o idólatra - o homem que vive magicamente -, a realidade reflete imagens. Podemos observar, hoje, de que forma se processa a magicização da vida: as imagens técnicas, atualmente onipresentes, ilustram a inversão da função imagética e remagicizam a vida. (2002, p. 9)

Dessa forma, a sociedade vem produzindo através de diferentes dispositivos tecnológicos, conforme argumenta Dubois (1999), uma Linha Geral, ${ }^{3}$ composta de máquinas de imagens que produzem uma estética da representação. Assim como no texto de Borges (1999) os homens de/da ciência buscam construir mapas/imagens que se assemelhem cada vez mais à "realidade". No texto, é a ciência cartográfica, com o rigor de seu discurso e de sua prática, que possibilita a construção de um mapa que se constitui em cópia fiel do Império, de tal forma que já não era possivel aos habitantes do reino distinguir entre um e outro.

Parece-me que, dessa forma, estamos todos fadados a permanecer cada vez mais, de forma intensa e impenitente, ${ }^{4}$ acomodados no fundo da caverna de Platão. Entretanto, ainda me remetendo ao conto de Borges (1999), lanço algumas questões: quais motivos teriam levado as gerações vindouras a recusar os mapas produzidos pelos cartógrafos? 0 que as levou a abandonar e/ou rasgar os mapas? Seria essa uma geração iconoclasta? Haveria nessa atitude uma crença na palavra escrita como (única) fonte da verdade?

Parece-me que o pequeno conto também permite entender que o processo de abandono dos mapas, a prática de rasgar os mapas, "rasgar" as imagens, também pode ser interpretado como um momento singular na história da civilização: a produção da escrita humana. Novamente lanço mão das contribuições de Flusser (2002), para refletir sobre esse aspecto:

No segundo milênio A.C., [...]. Surgiram pessoas empenhadas no 'relembramento' da função originária das imagens, que passaram a rasgá-las, a fim de abrir a visão para o mundo concreto escondido pelas imagens. 0 método de rasgamento consistia em desfiar as superficies das imagens em linhas e alinhar os elementos imagéticos. Eis como foi inventada a escrita linear. Tratava-se de transcodificar o tempo circular

3 Remeto à leitura do artigo de Pillippe Dubois (1999), intitulado $A$ linha geral (as máquinas de imagens).

4 Faço aqui uma referência à discussão apresentada por Susan Sontag (2004), em seu livro Sobre Fotografia. 
em linear, traduzir cenas em processos. [...] A escrita funda-se sobre a nova capacidade de codificar planos em retas e abstrair todas as dimensões, com exceção de uma: a da conceituação, que permite codificar textos e decifrá-los. (2002, p. 9-10, grifos do autor)

Ao rasgar as imagens e inventar a escrita, o ser humano não consegue escapar definitivamente da caverna e ter acesso ao mundo real e concreto. 0 que ocorre é que ele produz uma nova forma de permanecer no interior da caverna. Isto porque os textos não significam o mundo diretamente, mas o fazem através de “imagens rasgadas". Para autores como Flusser (2002) e Machado (2001) nascia aí uma luta simbólica entre texto e imagem, que teria seus desdobramentos, ao longo da história do Ocidente, nos ciclos de movimentos iconoclastas. ${ }^{5}$

Dessa forma, parece-me prudente apostar não em uma relação de oposição entre palavra e imagem, mas sim numa complementação em que tanto as palavras como as imagens podem e devem ser consideradas como meios de comunicação humana. Segundo Samain (2006), palavras e imagens devem ser consideradas como modos singulares, diferenciados, de pensar o mundo. Palavras e imagens são meios singulares de comunicação humana e, ao mesmo tempo, complementares.

\section{Mas, afinal, o que é uma fotografia?}

Pequena queimadura de luz sobre uma superficie sensivel - os nitratos de prata, pele e pelícu-

5 Arlindo Machado (2001) identifica três ciclos de movimentos iconoclastas: o primeiro ocorreu no período de interdição às imagens, pela tradição filosófica grega e nas culturas judaico-cristã e islâmica. O segundo ocorreu durante o Império Bizantino, nos séculos VIII e IX, quando a produção, a disseminação e o culto das imagens foi proibido. O terceiro ciclo ocorreu no século XVI, com a reforma protestante. Segundo o autor, esses três ciclos se ancoraram numa crença desmedida no poder, na superioridade e na transcendência da palavra, sobretudo da palavra escrita, podendo-se caracterizá-los como ciclos de "literolatria", isto é: um culto ao livro e à letra. la ao mesmo tempo - a fotografia é, na sua materialidade, tanto uma ferida como uma cicatriz, uma fenda aberta no tempo, uma rachadura do espaço, uma marca, um rastro, um indício. Corte e golpe, ela é essa superfície de signos múltiplos e complexos, aberta a um passado que já não existe mais e a um futuro que não chegou a ser. As fotografias são tecidos, malhas de silêncio, as pequenas peles, as películas das nossas vivências. (SAMAIN, 2006, p. 109)

Acredito que as questões elencadas acima remetem ao movimento de buscar compreender o que é a imagem fotográfica e, nesse percurso, também compreender como a mesma pode desencadear modos singulares de percebermos e olharmos o mundo. Alguns autores (BENJAMIN, 1994; SONTAG, 2004) têm destacado que após a invenção da fotografia a experiência humana se modificou substancialmente. Com a fotografia, através das lentes de uma máquina, o ser humano também inventa outras formas de olhar o mundo, criando uma nova consciência cultural e subjetiva do mundo.

O modo como Dubois (2007) compreende a fotografia é para mim bastante desafiador. Para ele, a fotografia é mais que uma imagem técnica; é também um ato icônico. A fotografia é uma imagem, mas, como tal, deve ser concebida como uma imagem em trabalho, isto é: algo que não se pode conceber fora de suas circunstâncias, fora do jogo que a anima. 0 autor ainda complementa, afirmando que a fotografia pode ser considerada como uma imagem-ato, assinalando que o ato incorpora o gesto de produção, recepção e contemplação da imagem fotográfica. Nessa mesma direção, Barthes (1984) diria que uma foto pode ser objeto de três práticas, de três emoções, de três intenções: fazer, suportar e olhar.

Nesse sentido, é importante destacar o caráter enunciativo das imagens fotográficas, bem como o papel do sujeito, seja ele o fotógrafo (Operator), a pessoa que observa e con- 
templa uma foto (Spectator) e, por fim, "aquele ou aquela que é fotografado, é o alvo, o referente, espécie de pequeno simulacro, de eídolon emitido pelo objeto, que de bom grado eu chamaria de Spectrum da Fotografia [...]" (BARTHES, 1984, p. 20).

Tanto Barthes (1984) como Dubois (2007) destacam um lugar relevante do sujeito em todos os momentos e papéis envolvidos no jogo da produção de uma imagem fotográfica. Dessa forma, parece-me bastante instigante assumir que assim como se pode considerar a imagem fotográfica como uma imagem em trabalho, em processo, também seja plausível assumir que os sujeitos desse ato estejam igualmente em processo.

Ao destacar essa dimensão de envolvimento dos sujeitos no jogo, no processo de engendramento e produção das imagens fotográficas, Dubois (2007) avança sobre algumas posições epistemológicas quanto à questão do realismo e do valor documental da fotografia. 0 autor toma como referência as contribuições da semiótica peirciana, para deslocar a imagem fotográfica de um estatuto de espelho do mundo (verossimilhança) - em que ela seria um icone - passando pela perspectiva de considerá-la como símbolo, no qual as imagens fotográficas deveriam ser analisadas como uma interpretação-transformação do real e, por fim, para assumir uma posição que considera a fotografia como um índice. Nessa perspectiva, a imagem fotográfica possui uma relação inseparável da experiência referencial, do ato que a funda. "A foto é em primeiro lugar índice. Só depois ela pode tornar-se parecida (icone) e adquirir sentido (símbolo)" (DUBOIS, 2007, p. 53).

Samain (2006), baseando-se nas proposições de Dubois (2007), apresenta-nos sua compreensão da fotografia. Para ele:

A imagem fotográfica é uma inscrição, uma marca, uma pequena queimadura de luz sobre nitratos de prata; sempre o índice de um real, e que não existiria sem o seu referente. Posso tocar a imagem fotográfica, apalpá-la. Ela tem uma textura, um peso, uma materialidade, mesmo se ela é, também, achatada, bidimensional, corte e golpe no tempo e espaço. (SAMAIN, 2006, p. 54)

Lissovsky (2006), em texto que trata das relações entre a fotografia e a história nos escritos de Walter Benjamin, desafia-nos a entender a fotografia como um objeto que contrai o acontecimento e o exprime na forma cristalizada da mônada. A imagem fotográfica como mônada expressa algo que se encontra "lá fora" no espaço-tempo. Condensa as dimensões de tempo: passado, presente e futuro. A fotografia é, ao mesmo tempo, irrupção e congelamento. Ainda segundo o autor:

Na fotografia, os dois modos da temporalidade - a fugacidade e a interrupção - evidenciam-se como o problema das condições de visibilidade: problemas de aura e da centelha. A foto oscila entre aquilo que the escapa e isto que nela se infiltra. (LISSOVSKY, 2006, p. 26)

No tocante ao processo de leitura e interpretação das imagens fotográficas, dada a sua natureza, o significado da imagem encontra-se na superficie e pode ser captado por um golpe de vista. Para Flusser (2002), deve-se permitir à vista "vaguear", como um flaneur, pela superficie da imagem. Para o autor:

Ao vaguear pela superficie, o olhar vai estabelecendo relações temporais entre os elementos da imagem: um elemento é visto após o outro. 0 vaguear do olhar é circular: tende a voltar para contemplar elementos já vistos. Assim, o 'antes' se torna 'depois', e o 'depois' se torna o 'antes'. O tempo projetado pelo olhar sobre a imagem é o eterno retorno. $O$ olhar diacroniza a sincronicidade imagética por ciclos. (FLUSSER, 2002, p. 8)

No entanto, esse processo pode garantir apenas uma apreensão superficial do significado da fotografia. Se procuramos capturar aquilo que "escapa" e aquilo que se "infiltra" 
na imagem fotográfica, devemos "mergulhar" na fotografia.

Barthes (1984) destaca a multiplicidade de leituras da imagem fotográfica e o modo como uma imagem pode animar seu espectador. $\mathrm{Na}$ relação que se estabelece entre a fotografia e o espectador, dois movimentos distintos apresentam-se: um da imagem em direção ao observador e outro do observador em direção à imagem. Ao primeiro movimento, Barthes (1984) denominou studium. O studium referese aos pontos sensiveis, às marcas que partem da fotografia e atingem o espectador, chamando-lhe a atenção. 0 studium refere-se a uma leitura da imagem fotográfica, com critérios e objetivos definidos, tendo mais a ver com uma metodologia para a abordagem da imagem, seja ela qual for.

No segundo movimento, denominado punctum, a ação/reação parte do espectador e o leva a acrescentar alguma coisa à foto. Segundo Barthes, "O punctum é aquilo que eu acrescento à foto e que, no entanto, já lá está" (1984, p. 82).

O punctum é algo que parece decorrer da própria imagem. É algo que nos toca, independente daquilo que nosso olhar busca. 0 punctum está ligado ao afeto, e por isso mesmo é difícil de comunicar e de compartilhar. "O Punctum seria, então, um detalhe na imagem que, por uma força que concentra em si, atinge o leitor e lhe mobiliza involuntariamente o afeto" (BARTHES, 1984, p. 82).

É da tensão, da relação, não necessariamente de oposição, mas de complementaridade, entre o studium e o puctum, que podem ocorrer novas leituras, compreensões da imagem. É a partir dessa relação, desse engendramento, que as imagens fotográficas podem ser vistas, revistas, "transvistas".

Nesse sentido, apresento algumas questões que remeto ao processo de formação de professores de educação física: é possivel pensarmos numa experiência formativa de professores de educação física que se concretiza por meio de sua mediação e interação com as imagens? É possível tomarmos as imagens fotográficas como elementos potencializadores de uma reflexão dos sentidos e significados atribuídos pelos docentes ao seu processo de formação profissional, inicial e continuada? A fotografia pode instaurar um movimento reflexivo de sentir o que se vê e pensar o que se sente? De que modo imagens fotográficas podem nos auxiliar a (re)pensar práticas de formação de professores/as de educação física?

\section{Narrativas da/na Formação de Professores de Educação Física}

Tendo como referência o conjunto de questões apresentadas ao longo desse texto, que remetem aos desafios da formação de professores/as de educação física, apresento a seguir o relato de duas experiências desenvolvidas por mim, em que busquei articular o uso de imagens fotográficas à produção de narrativas orais e escritas. 0 primeiro relato vincula-se a uma experiência desenvolvida no contexto de formação inicial. Já o segundo, apresenta um contexto específico de formação continuada.

No tocante à formação inicial de professores/as de educação física, destaco o processo de elaboração de narrativas (auto)biográficas no contexto de realização de um projeto de extensão denominado Ensino de Práticas Corporais na Educação Infantil: articulando a formação inicial e continuada, que tematizou os Diferentes Modos de Brincar nas Culturas Indígenas e Afro-Brasileiras, que tive oportunidade de coordenar. ${ }^{6}$

Ao longo do ano de 2015, estivemos envolvidos no processo de documentação dos en-

6 Tal projeto foi desenvolvido no curso de licenciatura em Educação Física da Pontificia Universidade Católica de Minas Gerais (PUC-Minas), entre os anos de 2013 a 2015. 
contros e práticas pedagógicas desenvolvidos junto às crianças, privilegiando-se os registros fotográficos e escritos.

Após a conclusão do projeto, os acadêmicos foram desafiados a selecionar um conjunto de fotografias que permitisse a eles produzirem narrativas que tematizassem os diferentes modos de ensinar e aprender práticas corporais na Educação Infantil, bem como evidenciar os diferentes sentidos e significados produzidos pelos sujeitos. Nesse momento, cada acadêmico selecionou fotografias que the permitiram narrar suas experiências e, ao mesmo tempo, identificar saberes produzidos e mobilizados ao longo do projeto. Além disso, como elemento potencializador da escrita, foram apresentadas aos licenciandos as seguintes questões: o que vejo? Como vejo? O que penso sobre o que vejo? Como o que vejo me toca? 0 que faço com o que vejo?

Para efeito desse texto, são apresentadas as narrativas elaboradas pela acadêmica Thaisa.

\section{Da criança que fui à professora que estou me tornando}

Figura 1 - Composição fotográfica elaborada pela acadêmica Thaysa.

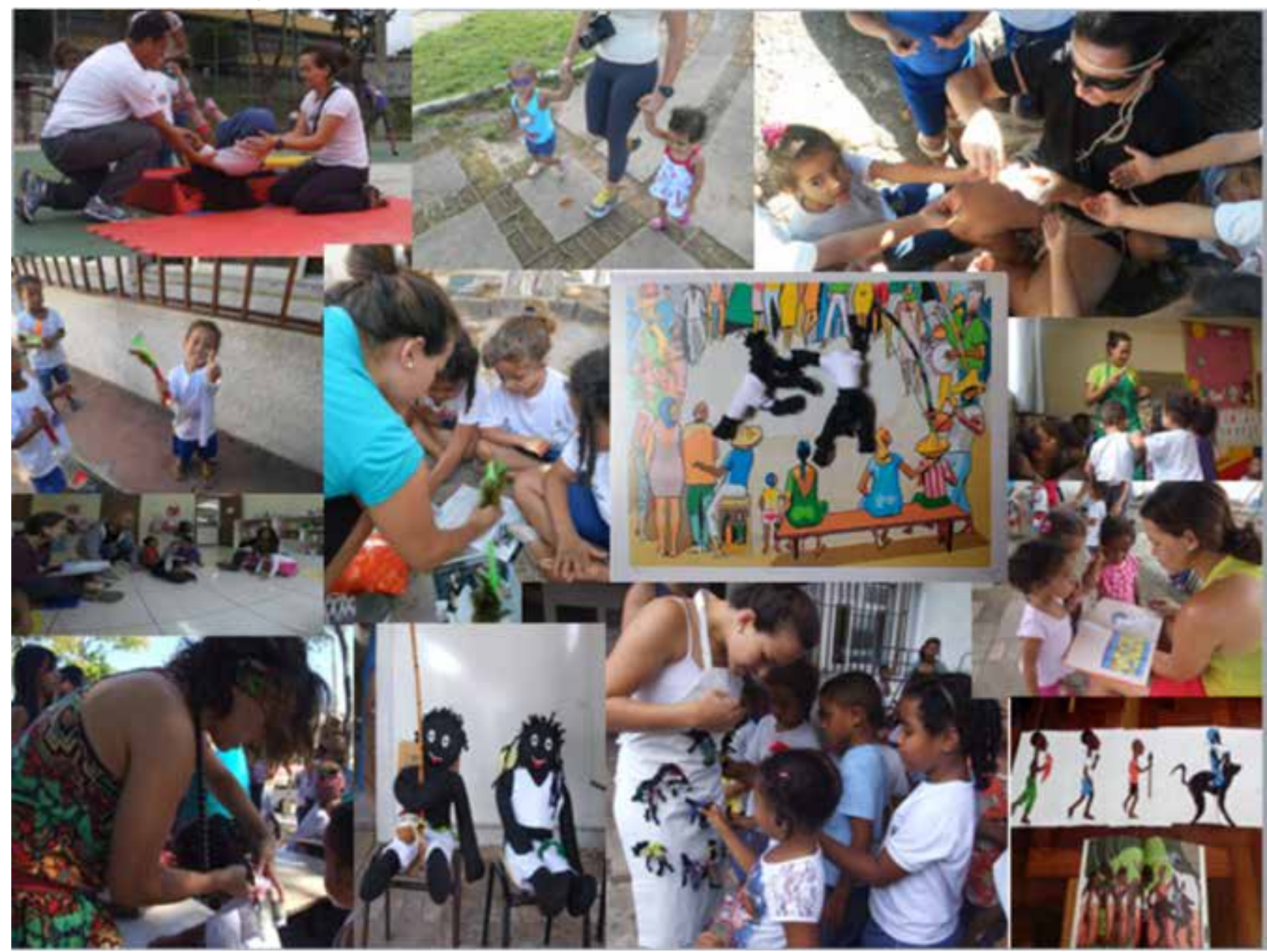

Fonte: Acervo do autor (2015).

Minha inserção no projeto de extensão se deu em um momento tênue da graduação: $a$ conclusão. Tratava-se de um momento que evidenciou ainda mais o "entrelugar" de aluna $e$ professora em formação, principalmente após três anos de inserção no PIBID. Entretanto, havia um desejo em atuar na educação infantil, seria mais um desafio em minha trajetória para um terreno desconhecido, e especialmente importante para amenizar meus conflitos no final 
do curso. A chegada à creche me fez relembrar do momento em que voltei à escola, durante a graduação, nossos olhares e os das crianças se cruzavam diante do novo. Nós éramos estranhos para elas, e elas novidade para nós. Durante o ano de 2015, desafios cotidianos foram superados na lida com o choro das crianças e ares de blasé diante das nossas tentativas de aproximação com brinquedos e atividades. Na contramão do desafio, as recompensas foram infinitas, ao me tornarem mais humana e educadora, ampliando meus olhares e sensibilidades na relação de ensinar e aprender com as crianças.

Durante o projeto de ensino Diferentes Modos de Brincar nas Culturas Indígenas $e$ Afro-Brasileiras, percebi o quanto me tornava professora à medida que reconectava as memórias da infância: sou e estou diante de um grande memorial formativo.

Fui uma criança que cresceu em Minas Novas, no interior de Minas Gerais, região do Vale do Jequitinhonha. Aos 14 anos, me mudei para a capital Belo Horizonte, para continuar os estudos. Meus pais continuam no interior e em minhas viagens de retorno, nas férias, me renovo nas constantes e mais singulares formas de simplicidade. Digo isso, pois só me dei conta desta rica experiência após sair de casa.

Se não me falha a memória, foi no primeiro período da faculdade, na construção de um memorial e na disciplina de jogos e brincadeiras, que me dei conta do que me constituiu e constitui como pessoa. Sou feita de gente. Gente que, de tanto ser rotulada de sofrida, pela falta de água e pobreza da região do Vale do Jequitinhonha, se empoderou e aprendeu a valorizar as ricas manifestações culturais presentes em festas, músicas, brincadeiras e artesanato.

Diante dessas percepções, me proponho a tecer e rememorar momentos dentro do projeto "Diferentes modos de brincar nas culturas indigenas e afro-brasileiras" que, para mim, são pérolas do grande colar que venho tecendo a partir das experiências formativas. Apresento a seguir três narrativas produzidas durante $o$ projeto.

\section{Da memória à Peteca}

Dando continuidade aos trabalhos da creche, na temática "Diferentes modos de Brincar nas culturas indigenas", nos propomos a construir brinquedos de origem indígena: a peteca (para as turmas de 4 e 5 anos) e a maraca (para as turmas de 1, 2 e 3 anos).

Propus a construção de uma peteca que aprendi a fazer na infância, com Tia Elisa. Lembro que estávamos na Fazenda do Papagaio, em Minas Novas-MG, e estávamos ociosos ou estagnados com as brincadeiras vivenciadas até o momento. Na época, acho que 1998, não era costume dos pais e das crianças levar brinquedos nos passeios, talvez os pais já pensassem no estímulo da criatividade ou simplesmente não queriam carregar brinquedos.

Assistindo àquela situação, Tia Elisa, como boa professora, sugeriu a construção de uma peteca. E logo pediu que buscássemos (eu e meus primos) argila no rio, penas no galinheiro e palhas no paiol (casinha onde ficavam os milhos da colheita). Com todos os materiais em mãos, construímos o brinquedo e nos divertimos durante o domingo a tarde.

Voltando para a creche e a proposta da peteca; separamos os materiais no dia do encontro: compramos argila no mercado, penas coloridas numa casa de festas, e nosso coordenador trouxe as palhas de Moeda-MG. Cheguei à creche junto com os colegas da PUC, fizemos um círculo com os alunos e contei uma estória sobre como os índios inventaram a peteca: "eles iam até o rio buscavam argila, pegavam penas de pássaros e palhas nas plantações de milhos e construíam as petecas... é o que faremos hoje!". 
Inicialmente, distribui os pedaços de argila e ouvi os comentários: "parece cocô", "nunca peguei em argila", "tem cheiro de terra moIhada". Não consegui ir direto para a base da peteca sem explorar o "momento argila" e conversar mais sobre ela. Em seguida, fizemos a base da peteca: "uma bolinha, uma pontinha, uma coxinha...". Depois cada criança recebeu as penas para fincar na base.

Pausa! Fomos brincar com outros tipos de peteca, enquanto as nossas secavam. Peteca de papel, peteca de pano com areia e petecas oficiais.

Voltamos para envolver e amarrar as petecas com a palha. Assim, as crianças ficaram felizes em levar suas petecas para casa, as educadoras felizes com nossa criatividade, $e$ eu particularmente feliz por contribuir com minhas memórias de infância na atividade.

\section{Da construção de um brinquedo à construção do meu brinquedo}

Como vamos iniciar a temática dos diferentes modos de brincar nas culturas afro-brasileiras? Essa foi a pergunta que permeou a cabeça dos extensionistas durante algumas semanas. Refletimos sobre o que foi desenvolvido no primeiro semestre de 2015, na primeira parte do projeto com os "diferentes modos de brincar nas culturas indígenas". Constatamos a necessidade de ampliar nossas leituras e discussões sobre as temáticas afro-brasileiras.

Para garantir um primeiro suporte teórico, o Admir nos apresentou um livro elaborado pelo Ministério da Educação, intitulado "História e Cultura Africana e Afro-brasileira na educação infantil". A partir da leitura, tivemos mais elementos para elaborar o primeiro encontro que denominamos de "Festa das Culturas Afro-brasileiras".

$\mathrm{Na}$ festa, realizamos oficina de pintura corporal com simbolos africanos, oficinas de capoeira e dança afro e oficinas de turbantes (onde eu estava). Me ofereci para costurar os turbantes das mais variadas cores $e$ foram dias na máquina de costura para "embainhar" os lenços que virariam turbantes. $A$ satisfação em costurar foi ampliada nos sorrisos das crianças já trajadas com turbantes. Sobre os turbantes, achei divertido o momento em que elas escolhiam a estampa e o quanto seus desejos, na grande maioria das vezes, não estavam impregnados das "amarras" da sociedade.

$O$ encontro da semana seguinte foi sobre os modos de brincar o pegador, nas culturas afro-brasileiras. Na semana anterior ao encontro, enquanto meus colegas confeccionavam as bonecas abayomis 7 para o avental, eu dava forma aos bonecos Griot e Griote. ${ }^{8}$ Inicialmente, as crianças ensinariam os seus modos de brincar o pegador e depois o Griot e a Griote apresentariam os modos de brincar nas culturas afro -brasileiras.

Como sou um ser de memória, me identifiquei muito com esses personagens e seus significados históricos. Vi meus colegas brincando de boneca, ao fazer e vestir cada abayomi, $e$ eu totalmente envolvida com o Griot e a Griote, os primeiros bonecos de pano que costurei. Só percebi minha relação com os bonecos, no dia em que eles foram apresentados às crianças. Puxa Griot dali, mexe no cabelo da Griote e corre com os bonecos pra um lado e pra outro... e eu pensando: "Meu Deus! Eles vão estragar meus bonecos!". Os bonecos geralmente ficavam comigo em minha casa, e a cada dia

7 As abayomis são pequenas bonecas de pano feitas apenas com nós, são consideradas símbolos da resistência feminina e africana. Eram confeccionadas pelas mães negras, para as filhas, durante as longas viagens de navio, e nos foram apresentadas pelo coordenador do projeto, que reservou uma tarde para nos ensinar a confeccioná-las.

8 Griot e Griote foram os nomes escolhidos por nós para os personagens que acompanhariam as crianças, durante o projeto. Em diferentes etnias africanas, o Griot é o responsável pela perpetuação da tradição oral. Algumas pessoas já nascem com a função de "ser" Griot. 
que antecedia os encontros eu brincava com os bonecos vestindo-os com a temática proposta: um dia estavam com roupas de banho, depois como capoeiristas.

E a cada dia as crianças iam estreitando $e$ tecendo relações com os bonecos: cochichavam coisas nos ouvidos dos bonecos, brincavam de casinha, de salão de beleza, levavam para os brinquedos do parquinho, entre tantas outras. Detalhe que as educadoras queriam que os bonecos ficassem lá, e eu disse que faria outros, mas aqueles eram nossos (meus!). E foi depois de muito desapego que fui percebendo que os bonecos eram pra elas e feitos pra elas: as crianças da creche.

\section{Encerramento e "retomamento"}

Ao avaliar o ano de 2015, no projeto de extensão, percebemos o quanto foi rico para as crianças, professoras e para o grupo de extensionistas. Mas como poderíamos encerrar o ano realizando uma espécie de retrospectiva?

A resposta veio através do livro "Num tronco de iroko eu vi a iúna cantar", adquirido pelo Admir. Em nossa ultima reunião de planejamento das atividades, Admir me emprestou o livro que acompanha um CD. Me propus a ler $e$ ouvir durante o fim de semana.

Fiquei maravilhada com o enredo, onde três meninos negros vivem aventuras para ajudar a Mãe Natureza e descobrem a capoeira, junto com personagens que são seres da cultura cabocla, negra e indígena. Era o que precisávamos para "amarrar" o projeto "Diferentes Modos de Brincar nas culturas Indígenas e Afro -brasileiras".

Logo sugeri para o último encontro com as crianças um teatro de fantoches com os personagens do livro. Infelizmente, não tínhamos tempo para ensaiar as falas e o CD tem duração de quarenta minutos. Meus colegas concordaram com minha sugestão e comecei a planejar $o$ encontro.
Comecei pela árdua edição do $C D$, alterando o enredo da estória com edição da cronologia e cortes das falas. O CD mudou de quarenta minutos para dez e a estória foi alterada para narrar a aventura dos três meninos negros na busca pelo berimbau do avô, que havia sumido. Pensei nesse enredo inspirada no livro "O segredo do disco perdido - uma aventura ao som do Clube da Esquina", onde um garoto busca pelo vinil Clube da Esquina do avô que desapareceu da casa durante um temporal.

Para nosso encontro na creche, fiz uma estrutura com caixa de papelão para o teatro de fantoches, bem semelhante a algumas que construí na infância. Pedi ao Admir que reproduzisse os desenhos do livro, para que eu fizesse as marionetes, colando os desenhos em palitos e facilitando seu manejo.

Ao dar cor aos desenhos com tinta, fiquei rememorando os diversos momentos do projeto. Lembrei da estória do Benedito, ganhando cor enquanto ouvia o som do tambor, e me vi em movimento semelhante: dando cor aos nossos personagens, enquanto ouvia o CD editado da estória. Acredito que este foi o momento em que meus fios da memória e do projeto ficaram mais resistentes, contemplando as experiências da criança que fui à professora que estou me tornando.

Considero que as narrativas elaboradas por Thaisa se constituem em um relevante dispositivo de formação. Ao incorporar às narrativas experiências vividas em distintos momentos de sua infância, Thaisa buscou identificar indícios dessas práticas em seu fazer cotidiano, convidando-nos a compreender como as mesmas se amalgamam a outras vivências e experiências e passam a constituir um conjunto de saberes que informam e conformam seus saberes e afazeres docentes.

Também considero importante destacar o modo como as memórias da autora, relacio- 
nadas a um conjunto de práticas corporais e modos de brincar constitutivos de sua infância, emergiram e deram forma às estratégias construídas coletivamente para o desenvolvimento das atividades. A dinâmica de trabalho possibilitou a Thaisa, e aos demais participantes do projeto, condições para a rememoração de suas experiências singulares, de suas memórias relacionadas à "brincação" ${ }^{9}$ e a suas "raízes crianceiras".

Parece correto afirmar que as memórias dos diferentes brinquedos e brincadeiras que emergiram nas narrativas podem se constituir em outras maneiras de apreensão e, também, de reinvenção das diferentes trilhas que levam à docência. Dessa forma, as fotografias selecionadas por Thaisa para a elaboração de sua composição ocupam um lugar estratégico no processo formativo da licencianda, possibilitando o movimento de reviver e escrever as várias experiências vividas e, sobretudo, compartilhá-las. 0 processo de elaboração das narrativas permitiu a Thaisa a aproximação e o entrelaçamento das memórias de sua infância, de diferentes maneiras de brincar - em diferentes tempos e lugares - como os fios constitutivos da experiência cotidiana de tornar-se professora.

A partir de agora, descrevo o processo de desenvolvimento de um trabalho de campo, realizado ao longo do ano de 2009 , em que tomei como pressuposto o poder de enunciação das imagens fotográficas articuladas às narrativas (orais e escritas), apostando que as mesmas apresentam e evidenciam diferentes tipos de saberes produzidos por professores/as de educação física no cotidiano escolar.

O trabalho de campo contou com a participação de um professor - Mauro - e três professoras de educação física: Renata, Ra-

9 A expressão Brincação é mais um dos muitos neologismos de Guimarães Rosa (1984), podendo ser encontrada na obra Corpo de Baile, mais especificamente em Uma estória de amor. quel e Celeste. Os docentes lecionavam na Rede Municipal de Educação de Belo Horizonte (RME-BH).

Dessa forma, iniciei um processo que denominei de acompanhamento da prática docente. Foram realizados, em média, dois acompanhamentos mensais a cada professor/a, no período de março a dezembro de 2009. 0 acompanhamento da prática docente privilegiou a produção de imagens fotográficas das aulas de educação física. Num primeiro momento, as imagens fotográficas foram produzidas por mim, entretanto, com o desenrolar do trabalho de campo, os/as professores/as e também os alunos passaram a produzir fotografias das aulas.

Ao final de um período médio de dois meses, as imagens fotográficas produzidas foram entregues aos docentes em mídia (DVD). Os docentes foram convidados a produzir uma seleção de imagens representativas do processo de trabalho desenvolvido naquele período. As imagens selecionadas foram reveladas e disponibilizadas aos/as professores/as.

A partir daí, teve início o segundo momento do trabalho de campo: a realização de reuniões individuais com os docentes. Foram realizadas quatro reuniões com cada professor. Nessas reuniões, os/as professores/as foram convidados a produzir, com as imagens selecionadas, uma narrativa visual, denominada arranjo visual, que thes permitisse contar suas experiências e práticas realizadas no cotidiano das escolas. As reuniões aconteceram nas respectivas escolas e foram registradas em vídeo, por duas câmeras - uma localizada à frente do docente, que procurava focar seus gestos e expressões na produção da narrativa visual, e uma segunda câmera, localizada acima do professor/a com a intenção de focalizar os movimentos exploratórios, realizados com as imagens fotográficas, no momento da composição da narrativa visual. 
Figura 2 - Primeira Narrativa Visual elaborada pelo professor Mauro.
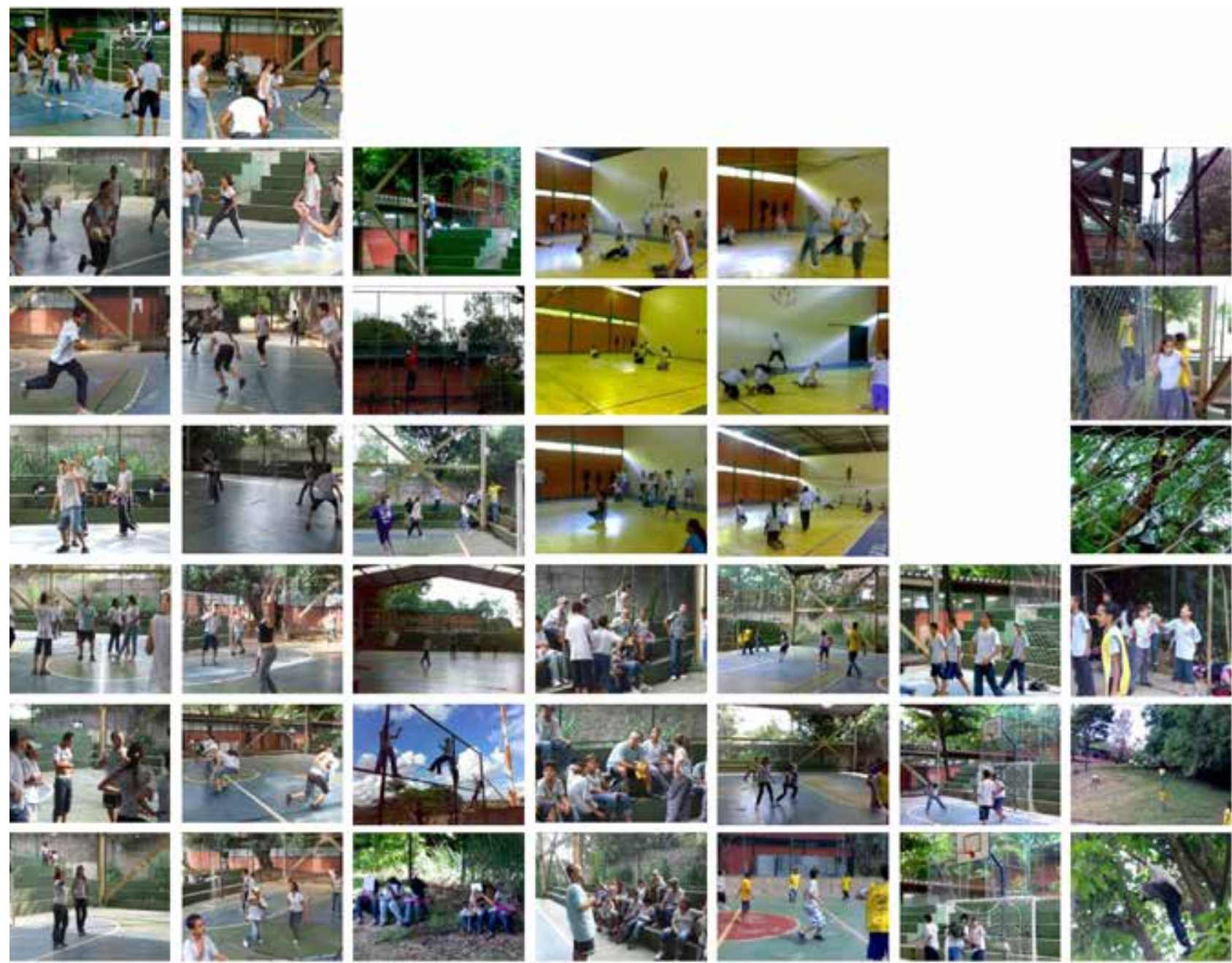

Fonte: Acervo do autor (2011).

A partir da composição do arranjo visual, solicitei aos docentes que narrassem e comentassem seu processo de trabalho, produzindo o que denominamos de narrativa oral. No final de cada reunião, os professores foram convidados a produzir uma narrativa escrita, a partir do arranjo visual.

As imagens e textos a seguir buscam apresentar as práticas, bem como alguns indícios das aprendizagens e saberes produzidos pelos docentes.

\section{Professora Celeste}

Vamos lá: o mês de maio foi o handebol!

Eu começo com uma brincadeira que é aquele jogo dos dez passes.

Depois que eu trabalho esse primeiro mo- mento, nesse grande jogo, onde todo mundo participa e não tem muitas regras, eu começo a trabalhar um pouco as... não vou dizer nem técnicas, né? Mas os fundamentos do esporte. Eu acho assim: depois, para ele jogar, ele vai precisar de certo domínio de bola, ele vai precisar de certo conhecimento de quais são os fundamentos para usá-los na hora do jogo.

Esta foto expressa o que pude observar em quase todos os últimos jogos. A garra do jogo, juntamente com a alegria e o entusiasmo. Enfim, o prazer de jogar. Acredito que muitos alunos não chegariam a este estágio sem passar pelas aulas de treinamento dos fundamentos básicos do Handebol. Se eu quero ensinar Handebol, eu devo ensinar como se joga. É possivel trabalhar o domínio de bola sem perder o lado 
lúdico da aula. Na foto, percebe-se claramente a turminha de colete fazendo a defesa e a jogadora sem colete na função de "pivô".

É engraçado, né? Eu fui ouvir falar de sociologia e educação fisica no PREPES... até então eu não havia pensado nessa dimensão... Eu estava muito mais preocupada com...

A conclusão que eu cheguei foi essa: an- tes eu era muito mais preocupada com o movimento que cada criança fazia do que com a própria criança! Então, depois que eu fui ver essa dimensão sociológica da educação física, eu acho que meu olhar está muito mais voltado para a criança que faz o movimento! E não para o movimento que é feito pela criança! E aí, eu sempre procuro ver isso...

Figura 3 - Composição fotográfica das aulas da professora Celeste.

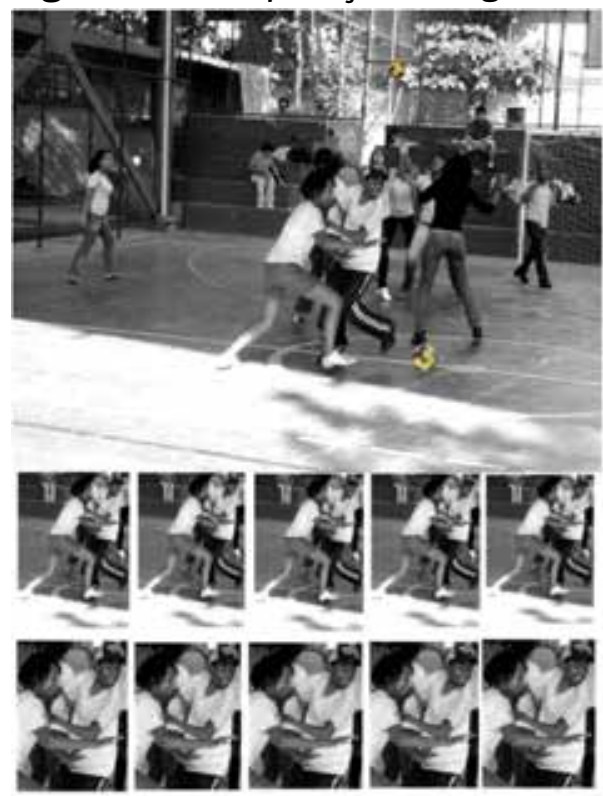

Fonte: Acervo do autor (2011).

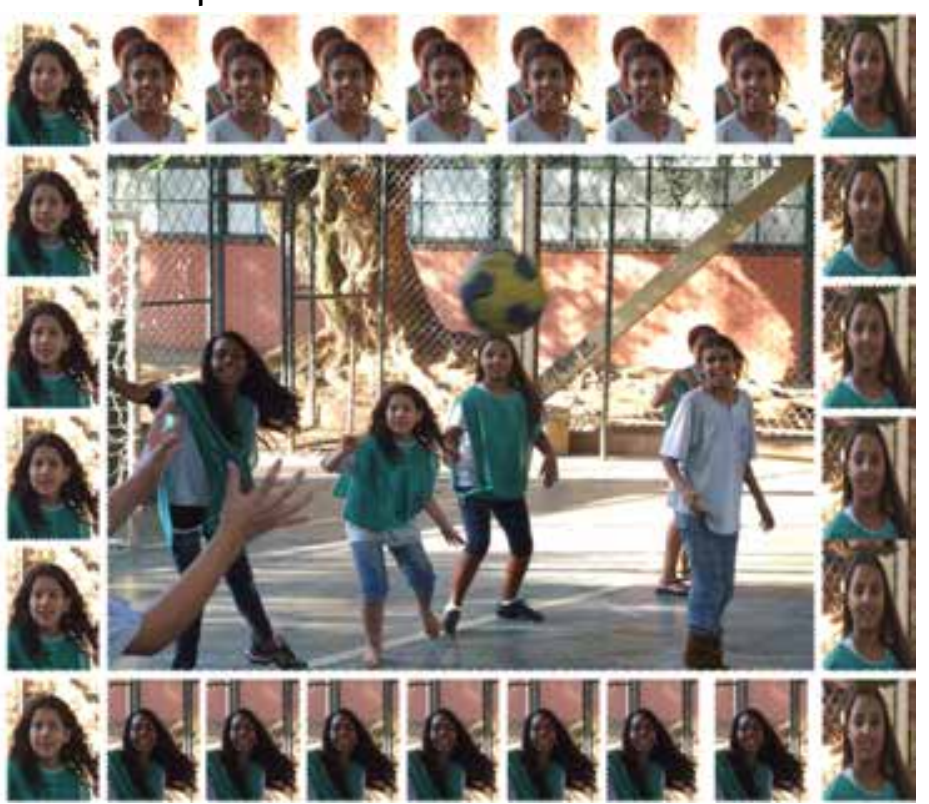

Neste dia na torre de telefone celular, que fica próximo à escola, havia trabalhadores subindo nessa torre, provavelmente para fazer a manutenção. A imagem apresenta tal "coincidência", a partir de construção de sentidos diferenciados dos sujeitos alunos(as) e trabalhadores em relação às suas práticas. aqui tem a menina tentando pegar!

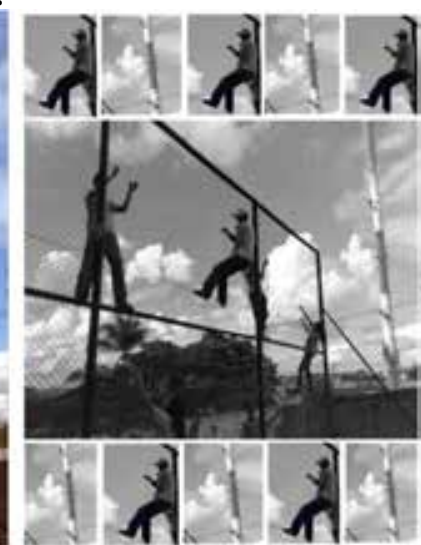

Fonte: Acervo do autor (2011).
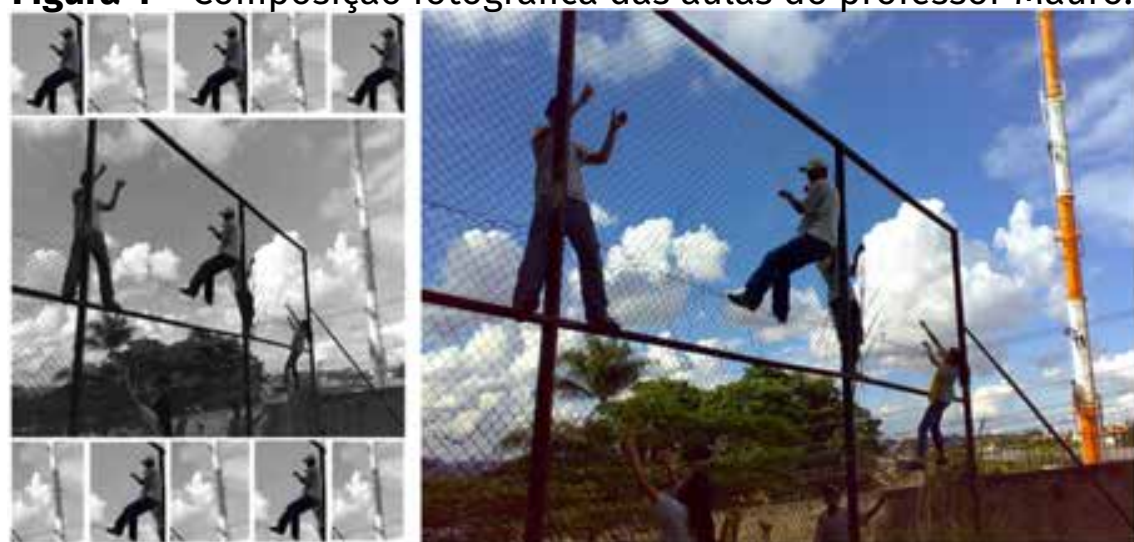

Figura 4 - Composição fotográfica das aulas do professor Mauro. 


\section{Professora Raquel}

Nessa outra foto aqui eu também estava - não tanto quanto a outra - eu estava observando... e não tinha notado essa atitude do Willian! Porque, se reparar, eu estava olhando para o outro lado, para o aluno que estava arremessando a bola. Então, eu não tinha visto que ele estava escondendo aqui! Eu vi a partir da foto! Que ele estava utilizando as duplas como escudo. Então, isso eu não teria como saber se não fosse... se não tivesse a foto. Porque são muitos estímulos o tempo inteiro, muitas coisas acontecendo na aula. Então, a foto me ajuda por isso: eu consigo recapitular, ver o que aconteceu e, às vezes, a partir daquilo ali, montar outra estratégia de aula.

Figura 5 - Composição fotográfica das aulas da professora Raquel.

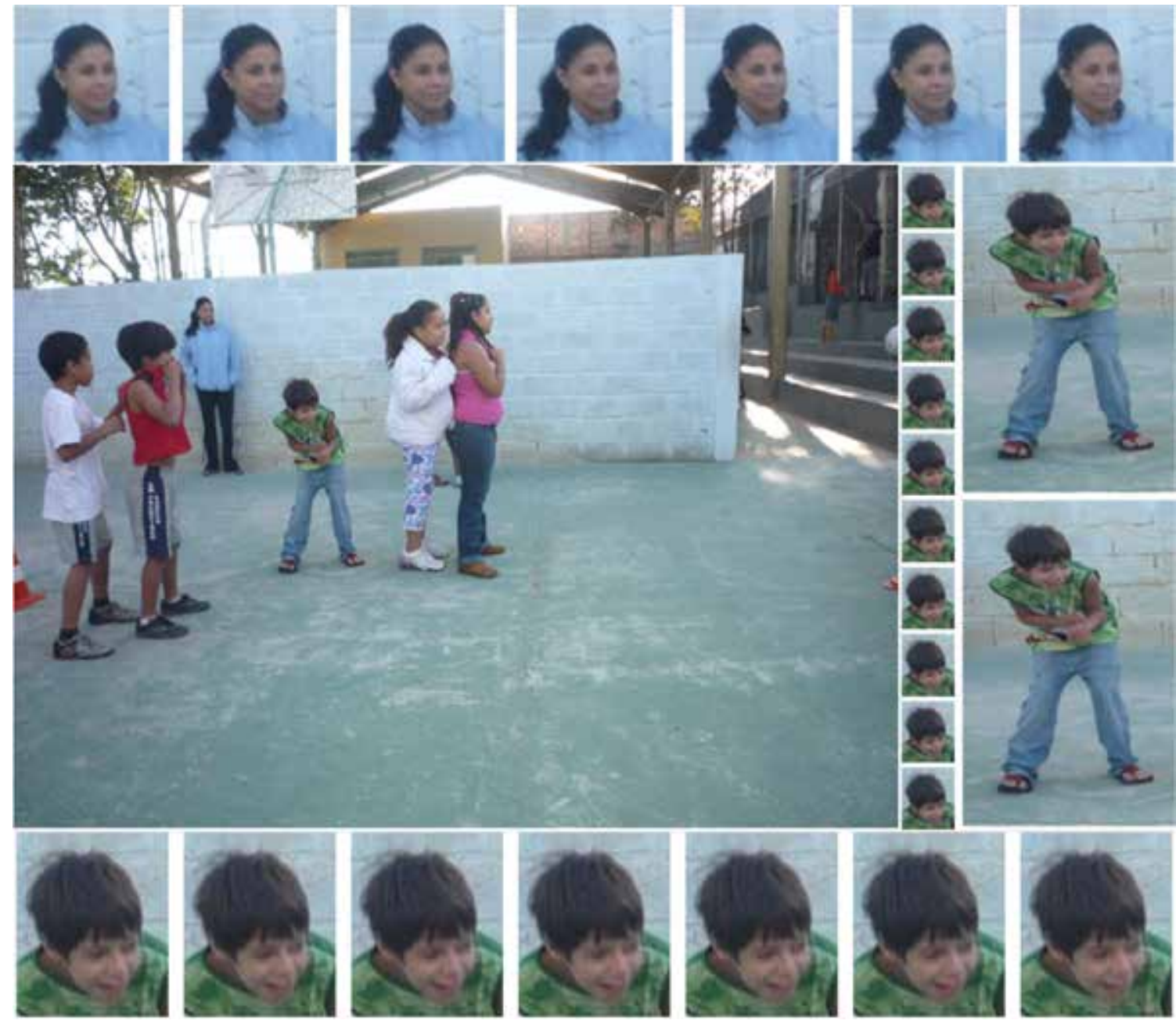

Fonte: Acervo do autor (2011).

\section{Professora Renata}

Achei interessante como uma foto dá tanta história, né?

Eu tive essa ideia porque eu precisava avaliar os alunos de alguma forma...

Eu pensei: vou utilizar essas fotos!

Como você já tinha proposto um exercício pra gente; de criar um relato em cima das ima- gens, eu achei que seria interessante fazer com eles...

Quando a gente vê a foto, percebe coisas que na prática a gente não se atenta: nossa postura, a postura do outro, eu achei que eles foram muito precisos nisso! Eles tiveram a intenção de captar o que estava acontecendo. 
Figura 6 - Composição fotográfica das aulas da professora Renata.
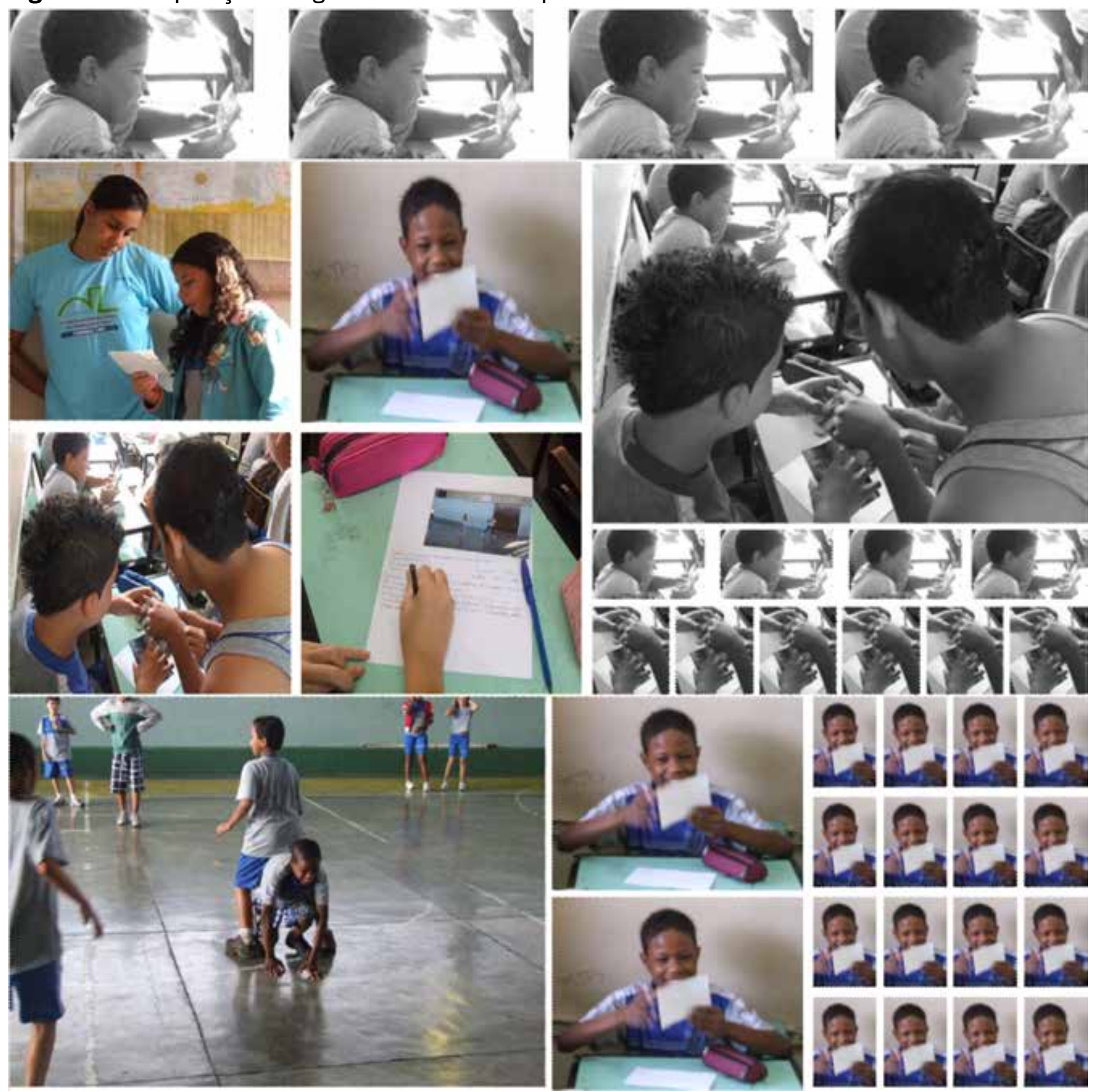

Fonte: Acervo do autor (2011).

A possibilidade de desenvolver o acompanhamento da prática pedagógica dos docentes aprofundou minha percepção da necessidade de se construir um tipo de pesquisa com professores/as, em contraposição a um conjunto de estudos que ainda se orientam por uma perspectiva de pesquisa sobre docentes de educação fisica. Nesse sentido, as narrativas produzidas pelos docentes constituíram-se em modos singulares de reflexão e de aprendizagem de uns com os outros. Trabalhar com narrativas na pesquisa e/ou no ensino mobili-

zou-nos para a desconstrução/construção de nossas próprias experiências tanto do lugar de professor/pesquisador como dos sujeitos professores/as de educação física. Dessa forma, as narrativas também contribuíram de modo significativo para o desenvolvimento de uma relação mais horizontalizada, menos hierárquica, entre o professor-pesquisador e os/as professores/as participantes da pesquisa.

Ao produzirem as narrativas visuais, orais e escritas, os docentes narraram suas experiências de trabalho em seus respectivos contex- 
tos de atuação. As narrativas permitiram aos/ as professores/as e a mim um intenso movimento de reflexão, interrogação e avaliação de nossas práticas, saberes, fazeres e afazeres.

No contexto de produção das narrativas, pude perceber que os docentes foram evidenciando um movimento de mobilização de saberes relacionados ao saber-ver, saber-observar e saber-ouvir os/as alunos/as, seus saberes e fazeres nas aulas de educação física (GARIGLIO, 2004).

As imagens fotográficas produzidas pelos diferentes sujeitos colocaram-se como potencializadoras do processo de reflexão da prática cotidiana dos/das professores/as de educação física. Dada a singularidade da fotografia que "congela", mas também potencializa a ressignificação de experiências, o processo de produção das narrativas visuais permitiu aos professores "mergulharem" e "flanarem" pelas múltiplas camadas das imagens fotográficas de suas aulas. Este "mergulho" nas imagens possibilitou aos professores um movimento de “[...] parar para pensar, parar para olhar, parar para escutar, pensar mais devagar, olhar mais devagar e escutar mais devagar; parar para sentir, sentir mais devagar, demorar-se nos detalhes [...]" (LAROSSA BONDÍA, 2002, p. 24). A cada novo "mergulho", os docentes encontravam possibilidades de rememorar e ressignificar suas experiências vividas junto aos estudantes nas aulas de educação física.

Dessa forma, é possivel afirmar que o conjunto de imagens fotográficas produzidas ao longo do trabalho de campo permitiu aos docentes rememorar e reconstruir as experiências vivenciadas nas aulas de educação física. As fotografias possibilitam ao professor Mau-

\section{Referências}

BAKHTIN, Mikhail. Estética da criação verbal. Tradução de Maria Ermantina Galvão G. Pereira. São Paulo: Martins Fontes, 2003. ro e às professoras Raquel, Renata e Celeste verem, reverem e também "transverem" sua prática. Nesse sentido, tendo como referência Bakthin (2003), é possivel afirmar que as imagens foram colocadas pelos docentes numa determinada posição exotópica e dialógica. Ao longo de todo o trabalho de campo, as imagens ocuparam um lugar estratégico, isto é, elas estiveram num lugar "entre" o professor - pesquisador e os docentes. Foi justamente a produção desse entrelugar que possibilitou a reflexão e a produção das narrativas.

\section{Algumas considerações finais}

Acredito ser importante que diferentes programas e propostas de formação inicial e continuada de professores/as de educação física considerem as potencialidades formativas das narrativas. No tocante à formação inicial, o trabalho com as narrativas e fotografias tem possibilitado aos/as licenciandos/as o reconhecimento e a valorização de seu processo de formação, assumindo uma postura de autoria em seu percurso formativo e percebendo-se como futuros/as professores/as.

No que se refere à formação continuada, considero relevante que as propostas busquem construir outros modos de aproximação e diálogo com os/as professores/as de educação física que atuam no cotidiano das escolas. Acredito que seja muito importante estabelecer condições institucionais que possibilitem aos docentes o movimento de produção de narrativas, visto que as mesmas se constituem em registros singulares que possibilitam a documentação de suas práticas bem como dos processos de produção de seus saberes cotidianos.

BARTHES, Roland. A câmara clara. Tradução de Julio Castañon Guimarães. Rio de Janeiro: Nova Fronteira, 1984. 
BENJAMIN, Walter. Obras escolhidas I - Magia e técnica, arte e política. Ensaios sobre literatura e história da cultura. Tradução de Sergio Paulo Rouanet. 7. ed. São Paulo: Editora Brasiliense, 1994.

BORGES, Jorge Luís Borges. História universal da infâmia. Tradução de Alexandre Eulálio. São Paulo: Globo, 1999. p. 27.

BARROS, Manoel de. Poesia completa. São Paulo: Leya, 2010.

BOTíA, Antonio Bolivar. "?De nobis ipsis silemus?": epistemología de la investigación biográfico-narrativa em educación. Revista Electrónica de Investigación Educativa, v. 4, n. 1, p. 1-26, 2002. Disponivel em: <http://redie.uabc.mx/vol4no1/contenido-bolivar.html>. Acesso em: 22 set. 2009.

DUBOIS, Phillippe. 0 ato fotográfico e outros ensaios. 10. ed. Campinas, SP: Papirus, 2007.

DUBOIS, Phillippe. A linha geral (as máquinas de imagens). Cadernos de Antropologia e Imagens, Rio de Janeiro, UERJ/NAI, v. 9, n. 2, p. 65-86, 1999.

FIGUEIREDO, Zenólia Campos. Os novos desafios da formação de professores de educação fisica no Brasil. In: SANTOS, L. L. C. P. et al. (Orgs.). Convergências e tensões no campo da formação e do trabalho docente. Belo Horionte: Autêntica, 2010. p. 341-351.

FLUSSER, Vilém. Filosofia da caixa preta: ensaios para uma futura filosofia da fotografia. Rio de Janeiro: Relume-Dumará, 2002.

GARIGLIO, José Ângelo. A cultura docente de professores de educação física de uma escola profissionalizante: saberes e práticas profissionais em contexto de ações situadas. 2004. 267 f. Tese (Doutorado em Educação) - Programa de Pós-Graduação em Educação, Pontifícia Universidade Católica do Rio de Janeiro, Rio de Janeiro, 2004.

GOODSON, Ivor. Conhecimento e vida profissional: estudos sobre educação e mudança. Tradução de Jorge Ávila de Lima. Porto: Porto Editora, 2008.

LARROSA BONDÍA, Jorge. Notas sobre a experiência e o saber de experiência. Revista Brasileira de Educação, n. 19, p. 20-28, jan./fev./mar./abr. 2002. Dis- ponivel em: <http://www.scielo.br/pdf/rbedu/n19/ n19a02.pdf>. Acesso em: 11 nov. 2008.

LARROSA BONDÍA, Jorge. Notas sobre narrativa e identidad. In: ABRAHÃO, Maria Helena Menna. (Org.). A aventura (auto)biográfica: teoria e empiria. Porto Alegre: EDIPUCRS, 2004. p. 11-22.

LISSOVSKY, Mauricio. Sob o signo do "clic": fotografia e história em Walter Benjamin. In: BIANCO, BelaFeldman; MOREIRA LEITE, Miriam L. (Orgs.) Desafios da imagem: fotografia, iconografia e vídeo nas ciências sociais. 5. ed. Campinas, SP: Papirus, 2006. p. 21-36.

MACHADO, Arlindo. 0 quarto iconoclasmo e outros ensaios hereges. Rio de Janeiro: Rios Ambiciosos, 2001.

NÓVOA, Antônio. Os professores e as histórias de vida. In: NÓVOA, António. (Org.). Vida de professores. Porto: Porto Editora, 2000. p. 11-30.

PASSEGGI, Maria Conceição. Narrar é humano! Autobiografar é um processo civilizatório. In: PASSEGGI, Maria Conceição; SILVA, Vivian Batista. (Orgs.). Invenções de vida, compreensão de itinerários e alternativas de formação. São Paulo: Cultura Acadêmica, 2010. p. 103- 130.

PRADO, Guilherme do Val Toledo; DAMASCENO, Ednaceli A. Saberes docentes: narrativas em destaque. In: VARANI, Adriana; FERREIRA, Claudia Roberta; PRADO, Guilherme do Val Toledo. (Orgs.). Narrativas docentes: trajetórias de trabalhos pedagógicos. Campinas, SP: Mercado de Letras, 2007. p. 15-28.

ROSA, João Guimarães. Manuelzão e Miguilim (Corpo de Baile). 9. ed. Rio de Janeiro: Nova Fronteira, 1984.

SAMAIN, Etienne. Modalidades do olhar fotográfico. In: ACHUTTI, Luís Eduardo. (Org.). Ensaios (sobre o) fotográfico. Porto Alegre: Editorial, 1998. p. 109-114.

SAMAIN, Etienne. Balinese character (re)visitado. In: ALVES, André. Os argonautas do mangue (André Alves): precedido de Balinese character (re)visitado (Etienne Samain). Campinas, SP; São Paulo: Editora da UNICAMP; Imprensa Oficial, 2004. v. 1. p. 17-67.

SAMAIN, Etienne. (Org). 0 fotográfico. 2. ed. São Paulo: Hucitec; Senac São Paulo, 2005. 
SAMAIN, Etienne. Questões heurísticas em torno do uso das imagens nas ciências sociais. In: BIANCO, Bela Feldmann; MOREIRA LEITE, M. L. (Orgs.). Desafios da imagem: fotografia, iconografia e vídeo nas ciências sociais. 5. ed. Campinas, SP: Papirus, 2006. p. 51-64.

SONTAG, Susan. Sobre fotografia. Tradução de Rubens Figueiredo. São Paulo: Companhia das Letras, 2004.
TERRA, Dinah Vasconcelos. A biografia-narrativa como estratégia de formação do professor de educação física. In: SANTOS, L. L. C. P. et al. (Orgs.). Convergências e tensões no campo da formação e do trabalho docente. Belo Horizonte: Autêntica, 2010. p. 352-362.

Recebido em: 10.08.2017

Aprovador em: 17.11.2017

Admir Soares de Almeida Junior é Doutor em Educação pela FE/UNICAMP. Professor Adjunto do Departamento de Educação Física da Escola de Educação Física, Fisioterapia e Terapia Ocupacional (EEFFTO) da Universidade Federal de Minas (UFMG). e-mail: admir.almeidajunior@gmail.com

Rua Manoel Miranda, 282, União, Belo Horizonte, Minas Gerais.

(31) 99804.8017 